\title{
SUPERPATRIOT OPPOSITION \\ TO COMMUNITY MENTAL HEALTH PROGRAMS
}

\author{
RICHARD SCHMUCK, Ph.D., and MARK CHESLER, M.A.*
}

\begin{abstract}
Superpatriots' concerns about mental health programs are explored. Superpatriots are defined by nationalistic conservatism, the perception of a major internal communist threat in America, and a commitment to action. Their opposition to mental health programs involves the belief that psychological testing invades privacy and that such programs are extensions of federal bureaucracy, encourage immorality, are ideologically biased, and are part of a communist plot to destroy America. Superpatriots who were interviewed were not disturbed or alienated. They were strongly fundamentalist in religion, dogmatic, moralistic, and informally associated with other superpatriots through neighborhood groups.
\end{abstract}

While most Americans support the growing national concern for mental health and the application of the behavioral sciences to community problems, some people are opposed to these developments. A wide variety of people object to mental health programs for many different reasons. One particular group of "opposers" is superpatriots. For them, anti-mental health attitudes are part of an embracing ideology and activism directed toward many contemporary trends. Not all superpatriots are opposed to mental health programs, however. It is the content and tenor of some typical superpatriot concerns about mental health programs that are explored in this report. Other data or insights into the psychology of superpatriotism as it relates to mental health may be found in Marmor, Bernard, and Ottenberg (1960), Auerback (1963), and Schiff (1964).

\section{A Definition of Superpatriotism}

Several major dimensions of belief and activity define superpatriotism. One dimension is a patriotic or nationalistic conservatism. The investigators measured this dimension by asking respondents about their political affiliation, their identification with liberal or conservative elements of each major party, and their reaction to the statement "Whereas some people feel they are citizens of the world, that they belong to mankind and not to any one nation, I, for my part, feel that I am first, last, and always an American."

A second major dimension is a vigorous anticommunism, not only with regard to international affairs, but especially to the internal danger of subversion. Many superpatriots attribute great power to the communists, who are seen as the "agent provocateur" of most of the world's and nation's ills. This dimension was measured by asking respondents how many communists there were and how much danger they represented in the American government and in both major political parties. A third defining dimension of superpatriots is their clear commitment to action. Lecture audiences, magazine or newspaper subscribers, and group members are urged "to do something" about their nation's condition. Action may

*The research reported here has been supported partly by the Anti-Defamation League and the Society for the Psychological Study of Social Issues. Dr. Schmuck is Associate Professor of Group Dynamics in the Educational Psychology Department, Temple University, Philadelphia, Pa. 19122. Mark Chesler is As. sistant Project Director in the Institute for Social Research, The University of Michigan. Thanks are due to Alvin Michaels, M.D., for his help on an earlier version of this report. 
involve becoming educated, educating others, protesting, or politicizing, but the commitment to some action is a critical part of superpatriotism. This dimension was measured by asking respondents how many partisan, sociopolitical organizations they belonged to that had regular meetings, and what they did to act upon their attitudes and values. Individuals who share the first two characteristics of the superpatriot ideology but do not act upon it are an important segment of the American population, perhaps even greater in number than the superpatriots. But precisely because they are not active opposers or resisters to change and are more passive, they are not the concern of this study.

In studying superpatriots' views, the authors first performed a content analysis of the literature published by extremist individuals and groups regarding mental health programs. Further, in order to ascertain whether such ideas were reflected in the beliefs of persons participating in superpatriot groups 62 superpatriots, were interviewed and their views compared with those of 38 conservatives and 34 moderates. These three groups were defined by their positions on an index composed of the three dimensions described above. Conservatives were defined as politically conservative and fairly nationalistic, but not particularly active, certainly not active in extremist organizations, and not believing that communists have a strong influence in government and in both political parties. Moderates ranged from traditionally moderate Republicans to moderate Democrats; they saw little communist influence in government, none in the political parties, and were not active in political organizations.

\section{Superpatriots' Concerns Regarding Mental Health Programs}

Mental health programs have been scrutinized and criticized by many people for many different reasons. The reactions range from scientific studies through literary critiques to ideological and political attacks. Much of this opposition does not come from superpatriot organizations and individuals. However, some virulent opposition is pre- sented in the writings and activities of superpatriots that can be summarized into five issues.

1. Psychological testing often constitutes an invasion of privacy and "brainpicking." Superpatriots are especially concerned with the use of psychological tests that assess personality characteristics. The concern for the use of such tests in the schools has been widely debated and some extreme criticisms have been entered into The Congressional Record (Ashbrook, 1962):

A school would be in serious trouble if it would undress students for examination or inoculate them with some serum without parental permission. Yet virtually the same thing is being done all the time through these brain picking tests which literally undress young people and interfere in private areas which would be better left alone.

Psychological testing and invasions of private beliefs are seen sometimes as dangerous extensions of "adjustment theories of education." In a special issue of The National Health Federation Bulletin devoted to "Counselors and the Schools" (1962), it was argued that the purpose of the Minnesota Multiphasic Personality Inventory, the Blacky Test, and other psychological inventories was to destroy the child's moral and spiritual foundations. The resultant moral vacuum was seen as the ideal condition for the further promulgation and acceptance of the doctrine of the "welfarepolice-slave state." It was also seen as providing:

... an opportunity for a vicious attack upon the children of the nation. Parents should not rest easy until they know exactly what is being done with their children and with others in the guidance counseling program in the school attended by their own children. Only united public action can stop this program of harm to children and of government control reaching into private thoughts and feelings.

In the interviews respondents were asked how they felt about psychological counseling in the public schools. Responses indicated that the superpatriots were much more opposed to psychological services in the school than were the conservatives and moderates. The results are presented in Table 1.

2. Community mental health programs are 
TABLE 1

REACTIONS OF SUPERPATRIOTS AND OTHERS to Psychological Counseling Services IN THE SCHOOLS

(Problems of adjustment and emotional problems have become an increasing concern of public schools in recent years. Many schools have hired professional psychologists and social workers to deal with these problems. Some people feel that such persons are beneficial in schools; others feel that they are more harmful to the children than good. Do you think that there should be such services in the elementary and high schools?)

\begin{tabular}{lccr}
\hline \hline & $\begin{array}{c}\% \\
\text { Yes }\end{array}$ & $\begin{array}{c}\% \\
\text { Ambivalent }\end{array}$ & $\begin{array}{r}\% \\
\text { No }\end{array}$ \\
\hline Superpatriots & 37 & 15 & 48 \\
Conservatives & 63 & 8 & 29 \\
Moderates & 80 & 7 & 13 \\
\hline
\end{tabular}

extensions of the federal bureaucracy. In general, the superpatriots are concerned with increasing federal control of health and welfare programs. Further, they are generally opposed to further federal expansion, aid to education, or urban renewal programs and fear the end of local and private initiative in the face of a vast federal bureaucracy. Some critics have interpreted federal mental health efforts as attempts to secure "dictatorial powers" (Brengel, 1963). In addition to a concern about centralized power, others feared that many state and community mental health programs provide for aliens and intellectuals to take charge of individual citizens in every phase of their lives. To be taken charge of, to lose personal and local independence, seems to be a major theme in superpatriot opposition to most federally financed programs.

The answers to one question in the interview also suggested that superpatriots would resist greater federal funds for mental health. The investigators asked for agreement or disagreement with the statement "Local medical facilities are inadequate." Table 2 suggests that whereas most citizens agree with this statement, superpatriots were more satisfied with current facilities.

3. Mental health practitioners encourage immorality, sin, and social disorganization.
One aspect of this view is that psychodynamic analysis de-emphasizes personal responsibility and encourages free expression and moral license. An example of these views of mental health was presented by Stormer in a widely distributed book, None Dare Call It Treason (1964). In discussing the psychiatric theories of Chisholm, Overstreet, and others, Stormer stated that:

The Chisholms faced by a patient overcome with guilt because of extramarital relations, homosexual practices, or other antisocial tendencies will devote their efforts to convincing the patient that such actions are perfectly normal, that no guilt should be experienced. This is an outgrowth of the materialistic, psychodynamic approach to understanding human behavior. This school holds that when an individual feels a drive that the drive must be satisfied or resulting tensions will produce insanity. ... Not relying on free will, morals or conscience for guidance, such amoral criminal minds are typical of the man Marx envisioned [pp. 162-163].

In addition, such a psychodynamic position has been seen as helping to identify "society" as the culprit when man errs. By finding root causes for deviant behavior in

TABLE 2

Reactions of Superpatriots, Others, and the General Public to the Inadequacy of Current Mental Health Facilities

\begin{tabular}{lcc}
\hline \hline & $\begin{array}{c}\% \\
\text { Inadequate }\end{array}$ & $\begin{array}{c}\% \\
\text { Adequate }\end{array}$ \\
\hline General public & & \\
Roper, 1950 & 73 & 27 \\
Jaco, 1955 & 79 & 21 \\
Crawford,* 1959 & 85 & 15 \\
Current study, 1964 & & \\
Conservatives & & \\
$\quad$ and moderates & 79 & 21 \\
Superpatriots & 50 & 50 \\
\hline
\end{tabular}

*See Crawford, Rollins, and Southerland, 1961.

the character of the social system, mental health workers are seen as absolving man of moral culpability. Attempts to change or reorganize aspects of the society are seen as threatening personal adherence to established norms.

Perhaps one reason superpatriots are concerned about the assumptions and implications of mental health programs is 
their general emphasis on morality and moral principles. In discussing the things about modern America that most disturb or worry them, the superpatriots who were interviewed concentrated upon "moral decay," "a loss of morality," or "not sticking up for American principles." The investigators also asked the respondents: "What are some of the names of the three greatest contemporary Americans? What is it about him or her that is great?" The most frequent person named by the superpatriots was General Douglas MacArthur. Superpatriots differed from conservatives and moderates in that they more often attributed greatness to him on the basis of "his strong moral character," or "fighting for his principles." Conservatives and moderates who suggested MacArthur most often did so on the basis of his "service to his country," "great intellect," or "brilliant generalship." This perspective on traditional moral values is also evident in the finding that superpatriots were more strongly antihedonistic as compared to others. The investigators asked for agreement or disagreement with the statement: "Since life is so short, we might as well eat, drink and be merry and not worry too much about what happens to the world." Most interviewees disagreed with that statement, but $72 \%$ of the superpatriots, compared with $31 \%$ of the conservatives and $26 \%$ of the moderates, strongly disagreed with the statement.

4. Mental health programs are politically and ideologically biased. Often, mental health programs are seen as masking political policies of internationalism and racial integration. Brengel (1963) and McClay (1964) expressed this concern in interpretations of materials of the World Federation of Mental Health. The WFMH discusses some of the psychological and social problems created by prejudice, hostility, and excessive nationalism and was seen by these commentators as being com. mitted to political positions rather than to health concerns. Another writer (Matthews, 1958) has criticized the World Health Organization, which is seen as an attempt to "internationalize" and "one- worldize" the American citizenry. WHO's concern for worldwide mental health has been interpreted as a plan to change the political, social, and economic institutions of society as well as to cure individual health problems.

One of the John Birch Society's directors expressed a similar fear about the partisanship inherent in current mental health policies. He noted that General Walker was forced to undergo a psychiatric examination but that the Freedom Riders were not (Anderson, 1962). Recently, news reports indicated that a southern mental health society was picketed by the Ku Klux Klan. The Klan distributed literature claiming that the purpose of the society was to brainwash Southerners into accepting integration and that lobotomies would be performed, making them submissive to communism and integration (Robinson, 1965).

Mental health program directors are sometimes seen as ideologically committed to liberal political ends. They are also seen as having power to refer or confine people to mental institutions. Consequently, mental health practitioners may be viewed as using their power for insidious purposes of controlling the thoughts and actions of the citizenry. In one view, people have been put into mental institutions because they are opposed to the "established liberal order."

One of the most dramatic case studies of this concern about mental health programs and political thought control revolved around a federal bill originally intended to finance a mental hospital in Alaska. Superpatriots interpreted this as the beginning of "Siberia, USA." A concise summary of this superpatriot concern was presented in Stormer's book:

For the rare citizen who escapes indoctrination in the new social order in progressive schools, for the Bible believing Christian who rejects theologians who teach that socialism is the new kingdom of God on earth, for all the sturdy souls who hold to age-old concepts of right and wrong and are vocal about it; the collectivists have one final, ultimate weapon. Declare them insane! . . The new leaders in the psychiatric field ... hold the weapon of commitment to a mental institution over the heads of those reactionaries who rebel at accepting the new social order [p. 155]. 
5. Finally, there is the concern that mental health and mental health practitioners are part of the communist plot to destroy America. Several superpatriot attacks in this vein were documented in the article "Is Mental Health a Communist Plot?" in the $S . K$. and F. Psychiatric Reporter (1962). One description of the psychiatrist Chisholm that subtly presented this theme was delivered in a speech by a prominent superpatriot:

While I do not contend he is a member of the Communist party, his philosophy calls for, freely and in sophisticated terms, the main key points of Communism, namely: an amoral society, ridicule of the family, of religion, and of patriotism, ruthless world-wide police force, and redistribution of wealth. Mental health enthusiasts decry as preposterous the many documented charges of Communists being active in the movement; in fact, they don't want to discuss such irresponsible criticisms. But there are plenty such connections.

The Russian leader, Beria, is said to have extolled the virtue of psychopolitics, skilled psychological manipulations for political ends. He is reported to have set out to train American psychopoliticians to take over our nation. Many American psychiatrists are viewed as foreigners who were educated in Russia. A spokesman for the Public Relations Forum also elaborated upon the perceived extent of such communist infiltration:

If you are an officer in any club that wields some power, you doubtless have your psychopolitician. ... If he or she is not a real psychopolitician and is really working in your best interests, then there are others who will eventually turn you against her and have her fired so that a psychopolitician can replace her. Now more than ever before, it is necessary to keep your wits about you. When confusion reigns supreme, the Communists make their greatest inroads.

\section{Personal Characteristics and Recruitment Patterns of Some Superpatriots}

Although some of these views of mental health programs may seem extreme, the interviews suggested that superpatriots opposed to mental health programs were not typically psychotic, irrational, or disturbed; rather, they appeared to be socially effective and hospitable. For the most part, they seemed to be pleasant, considerate, and law abiding. Generally, they appeared to be comfortable and happy with their familial relations. Furthermore, they were not particularly dissatisfied or frustrated with their jobs or bureaucratic roles. In fact, within the present sample of superpatriots, little sense of personal anomie or demoralization was found. They were very much in touch with the world and were quite well informed and active in public affairs. The sample included people of all ages and social statuses. There were college students, young adults, middle-aged and older persons. They held all kinds of jobs and ranged from lower or lower-middle class to upper-middle or upper class.

Superpatriots were originally defined in part by their active involvement in public affairs. However, they also indicated more optimistic feelings of political effectiveness compared with the conservatives and moderates. Over $90 \%$ of the superpatriots either agreed or strongly agreed with the statement that "Working in groups is one way people like me can influence the government." Compared with others, these people did not feel politically alienated or helpless. They felt involved in, although in disagreement with, the processes of local and federal government.

Another pervasive characteristic of superpatriots was their religious fundamentalism. Respondents were asked about their beliefs in God, in an afterlife, in punishment and rewards in the afterlife, and in the literal interpretation of the Bible. Those people who agreed strongly with all of these items were identified as religious fundamentalists. So-called religious modernists were those who had a belief in God and immortality but who minimized the idea of punishment in the afterlife and who disagreed that the entire Bible should be taken as literal truth. Nonbelievers were those who disagreed with all of the questions. Seventy-two per cent of the superpatriots, compared with $49 \%$ of the conservatives and $32 \%$ of the moderates, were classified as fundamentalists.

In addition to this religious perspective, the superpatriots, in contrast to conservatives and moderates, scored higher on items to measure dogmatism (Rokeach, 1960). It appeared that they tended to reduce differ- 
ences in the environment, especially when they viewed the objects of consideration to be evil. Other results of the interviews that showed the superpatriots reducing differences were that they engaged in stereotypic thinking about Jews. However, they showed little emotional fervor and hatred of Jews. Oversimplification of thought, involving reduction of information rather than hatred, characterized these superpatriots' views.

Many people with similar characteristics never express them through political means and never endorse superpatriot views. Moreover, such personal characteristics alone would not lead one to become an active member in superpatriot organizations. Some organizational means and supports must exist to channel and recruit these persons into existing groups and activities. In building local chapters, superpatriots often rely on neighborhood contacts and friend. ships. Members usually probe one another about their interested friends and are encouraged to invite newcomers. The approach is one of inclusion rather than exclusion: so long as a person shares an ideology and attitudes close to that of the superpatriot, he is recruited and readily accepted. Membership in religious or ethnic minorities does not typically disqualify or discourage a person from active membership. In this open search for new recruits, members are trained to inform others about the work of the organization and are taught that all good Americans, whoever they are, are likely to agree with the patriots once they are informed.

In some places, organizations such as the John Birch Society execute a subtle and well-planned introduction into the society. Typically, induction first involves convincing a new participant of the expertise of the chapter leader and other members, then interesting him in reading some of the society's literature, and finally getting him to recruit other members. In one of the interviews this story about Mr. X (superpatriot) and Mr. Y (John Birch Chapter leader) was told to the interviewer.

$\mathrm{X}$ told me he has been feeling quite helpless about the world situation and had little information about it until he ran into the Birch Society. His first contact was going with neighborhood friends to $\mathrm{Mr}$. Y's house in another town for a meeting. He had little to say about the meeting but was very impressed with the Birch library which he claimed had books and information you couldn't get anywhere else. The library is a lending library. He showed me a book, Nine Men Against America, which he had borrowed. He told me that the Birch Society teaches people that things don't have to keep going this way and that they can influence events as individuals. They must start work in the community-in the PTA-the local political parties and local government, then work up to the state and finally the national level. He started talking to the other employees where he works. At first, he claimed, they didn't know much about what was going on. But he told them things gradually, and now they can talk about a lot of things together. $\mathrm{He}$ has given them some pamphlets and lent them some books, but hasn't identified these as from the Birch Society. "Eventually, I will," he says, and hopes at least one or two will join.

In addition to neighborhood contacts and friendships, many superpatriot groups use the technique known as "popular fronting," i.e., identifying one's cause with a popular public issue while at the same time working out a more broadly based ideology. For instance, superpatriot-sponsored antifluoridation programs may sometimes have the effect of bringing Christian Scientists into a multifaceted group. Right wing campaigns against urban renewal attract some urban landowners, while anti-Negro organizations in the cities, such as the National Association for the Advancement of White People, may attract urban whites. Protests at PTA meetings over curriculum materials or the recommendations of counselors may recruit some disgruntled parents into an antischool or anti-mental health campaign. Once in any of these specific-type campaigns, the new participants receive literature, make new friends, gain new satisfactions, and may gradually be brought into broader activities. Sometimes they may be persuaded to form new opinions against community mental health programs.

One particularly salient topic for recruitment recently involved the Supreme Court's decision regarding praying in the schools. The investigators asked the interviewees: "How do you feel about the Supreme Court decision against praying in 
the school?" Most of them, including a large number of moderates, were opposed to the decision. Ninety-two per cent of the superpatriots, $73 \%$ of the conservatives and $60 \%$ of moderates disagreed with the ruling.

Since a large number of people opposed the Supreme Court decision, many of them were probably receptive to attempts to protest that decision. One can understand the broad public appeal of Project America, a product of the "20th Century Reformation Hour." This project organized mass rallies and petitions that asked for a constitutional amendment to overturn the Supreme Court's decision. Many conservatives and moderates were active in this superpatriotorganized protest. Under such circumstances, persons with a generally conservative to moderate outlook, or dogmatic fundamentalists who have been apolitical, may be recruited into other superpatriot activities, such as anti-mental health campaigns.

In all of these activities, involvement and commitment in superpatriot organizations have the effect of raising participants' feelings of esteem, status, and political effectiveness. This cycle of gratification serves to encourage members to be active and to seek continually new recruits to their organizations and ideology.

\section{REFERENCES}

Anderson, T. Mental health. The independent American, 1962, 8 (7), 4.

AshBrook, J. Brainpicking in school: a study of psychiatric testing. Hum. Events, 1962, 19 (46), 883-886.

Auerback, A. The anti-mental health movement. Amer. J. Psychiat., 1963, 120, 105-111.

Brenget, M. H. Mental health bill-a new weapon for the Kennedy brothers? The independent American, 1963, 9 (1), 3.

Counselors and the Schools, Nat. Hlth Fed. Bull., 1962, 8.

Crawford, F., Rollins, G., \& Southerland, R. Variations in the evaluation of the mentally ill. J. Hlth hum. Behav., 1960, 1, 211-219, 2, 267275.

Gurin, G., Veroff, J., \& Feld, S. Americans view their mental health. New York: Basic Books, 1961.

Is Mental Health a Communist Plot? $S . K . \& F$. psychiat. Reptr., 1962, Sept.-Oct.

Marmor, J., Bernard, V., \& Ottenberg, P. Psychodynamics of group opposition to health programs. Amer. J. Orthopsychiat., 1960, 30, 330345.

Matrhews, J. B. The World Health Organization. Amer. Opinion, 1958, May, 7-12, 31-35.

McClay, Ellen. Bats in the belfry. Los Angeles: Rosewood, 1964.

Rosinson, C. The far right's fight against mental health. Look, Jan. 26, 1965, 30-32.

ROKEACH, M. The open and closed mind. New York: Basic Books, 1960.

SCHIF, L. The campus conservative movement. Unpub. Doctoral Diss., Harvard Univ., 1964.

Stormer, J. None dare call it treason. Florissant, Mo.: Liberty Bell Press, 1964. 